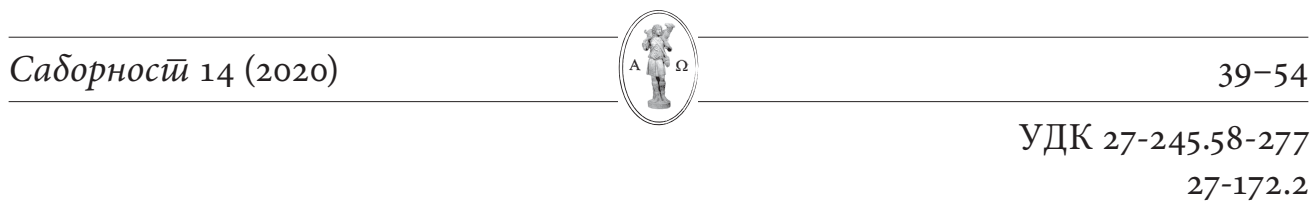

DOI: $10.5937 /$ sabornost2014039D

Оригинални научни рад

\author{
Aleksandar Danilović \\ Christian Cultural Centre dr Radovan Bigović, Belgrade
}

\title{
Faith in Ressurrection of the Dead and Creatio ex nihilo in 2 Macc 7
}

\begin{abstract}
The narrative of the martyrdom of a mother and seven brothers has had an enormous impact on the history of both Church and Synagogue. The cult of the Maccabean martyrs began to develop very early, so that in the fourth century at the latest, they were celebrated among the Christians. The story about them is to be found in the seventh chapter of the Second Book of Maccabees. Its canonical status has become the subject of debate in the last few centuries, both among the Orthodox and other Christians. The Synagogue rejected this book in its entirety, although it contains the oldest recorded testimony about the celebration of Hanukkah, one of the most important Jewish holidays today. However, the story of the mother and brothers remained preserved in Talmud in a certain form. Apart from the story of martyrdom, the seventh chapter hides one of the oldest, and certainly one of the most vivid descriptions of the early faith in the resurrection from the dead. In addition, the seventh chapter reveals the oldest explicitly expressed faith in God, who is the absolute Creator and who creates the world out of nothing. This idea will later become one of the central motives of Christian and Jewish cosmology.
\end{abstract}

Key words: resurrection, creation, ex nihilo, Maccabees, martyrs, Old Testament, deuterocanonicals.

\section{Introduction}

$\mathrm{T}$ he book, named the Second Book of the Maccabees (hereinafter 2Macc), already confuses the reader with its title. It is not a sequel to $1 \mathrm{Macc}$, but rather exists as a parallel storytelling. It focuses not so much on the history of the Maccabean Revolt against the Seleucid rulers, as 1 Macc does, but rather on the events that preceded this uprising and the early successes of Judah Maccabee. As the author himself (epitomator) states (2Macc 2:23), 2 Macc is a condensed version of a five-volume work by a certain Jason of Cyrene. Clement of Alexandria also men-

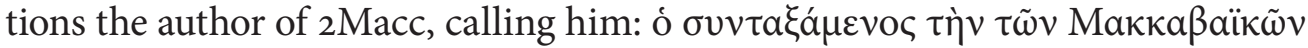
$\dot{\varepsilon} \pi \imath \tau \mu \eta v^{1}{ }^{1}$ About Jason himself, as well as the writer of $2 \mathrm{Macc}$, we do not know

\footnotetext{
aleksandar.danilovic.014@gmail.com

1 GCS 15, Strom V: 14.97, 390.
} 
much about, however it has been assumed that they belonged to the Jewish diaspora. ${ }^{2}$ When it comes to the raw structure of the book, one can find two epistles at the beginning of the book (2Macc 1:1-2:18), which are followed by a narrative.

The date of composition is not easy to determine, and scholars propse various dates. ${ }^{3}$ However, perhaps the most widely accepted dating is offered by Abel and Habicht. Reading the date given in the epistles (2Macc 1:10a), ${ }^{4}$ and assuming that the text precedes the epistles, they suggested that the 2 Macc was completed in 124 BC. ${ }^{5}$ Contrary to them, Schwartz offers a very interesting reading of $2 \mathrm{Macc}$ 1:10a, and dates the first epistle even earlier, to $143 \mathrm{BC} .{ }^{6}$ If so, the work of the epitomator has to be dated somewhat earlier. This would make 2 Macc older than 1 Macc.

Besides its historical purpose, $2 \mathrm{Macc}$ is also a deeply theological book that firmly supports the idea of preserving the Temple for the salvation of the People (2Macc 5:19). Along with Isaiah, Daniel, and some of the Psalms, 2 Macc is one of the oldest testimonies that explores the idea of faith in the resurrection of the dead. Connected with such faith, the theology of martyrdom is present. For the first time in the Jewish writings, 2 Macc introduces the concept of creating a world from nothing. In addition, the 2 Macc contains a sublime theol-

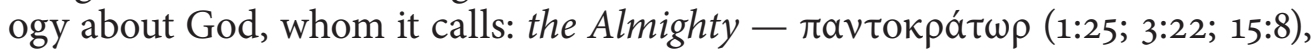

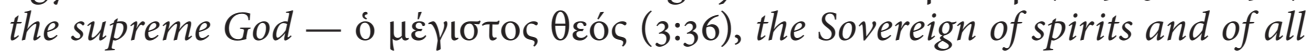

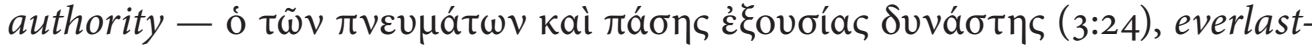

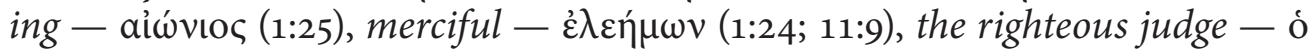

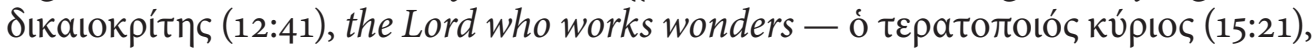

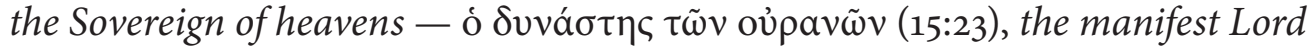
- ó Ė

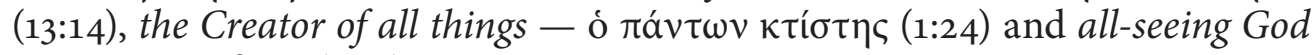

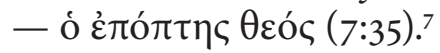

In the Early Church, 2 Macc was widely accepted, especially in the context of the martyrology (e.g. Origen, homilies of Gregory the Theologian and John Chrysostom). 2Macc was one of the primary sources for the author of the later

2 Doran, 2012, 15-17.

3 The date ranges from the second half of the $2^{\text {nd }}$ century BC to the fall of Jerusalem in 70 AD.

4 They consider date in $2 \mathrm{Macc} 1: 7$ to be a date of an earlier epistle.

5 Abel, xlii-xliii; Habicht, 1976, 174-175.

6 Schwartz, who favors minuscules 55 and 62, states that the year $188(\mathrm{P \Pi} \Delta$ ) of the Seleucid Era (SE), as evidenced by Alexandrinus and Venetus, is actually 148 (PM $\Delta$ ) SE (164/5 BC). This does not represent the date of the epistle, he believes, but the date of the first celebration of Hanukkah, when the Temple was rededicated. Thus, Schwartz regards the year given in 1:7a as the year in which the epistle was written, that is, 169 SE (143/2 BC). Schwartz, 2008, 11-15. Doran, on the other hand, rejects this claim, saying that Schwartz does not provide any parallel in Greek literature that could prove such a dating of epistles, yet he himself does not suggest any date of writing. See: Doran, 2012, 14-15.

7 Comp: Jevtić, 2002, 75. 
4 Maccabees. Other fathers and theologians of the early Church, such as Hippolytus of Rome, Gregory of Nyssa, Ambrose and Jerome also interpreted, used, and quoted $2 \mathrm{Macc}$ - Chapter 7 in particular.

Martin Luther marked 2Macc as apocryphal, despite translating it. The Roman Catholic Church, on the other hand, has considered it as Scripture since the Council of Florence in $1442 .{ }^{8}$ In the Eastern Orthodox Church, 2 Macc is considered to be part of the so-called Deuterocanonical books of the broader canon. Their status is yet to be determined, something which can be resolved at the upcoming Pan-Orthodox Council. ${ }^{9}$

\section{One of the oldest martyrdom stories $-2 \operatorname{Macc} 7$}

Chapter 7 of 2 Macc tells the story of the martyrdom of a mother and seven brothers. Together with the account of Eleazar's death from the previous chapter, this is perhaps one of the most recognizable narratives in $2 \mathrm{Macc}$.

Similar to Chapter 6, the reason for the occurrence of martyrdom here is the refusal of the mother and her children to break ancestral laws $(7: 2)$ and to eat forbidden swine meat $(7: 1)$. Unlike the unnamed Hellenized Jews who tormented Eleazar in the previous chapter, King Antiochus IV is here depicted as the tormentor of the mother and her sons. Enraged by the monologues of the brothers in which they bravely defy the torment, the king commands that they should be tortured to death $(7: 3)$. It is interesting to note that while the name of Eleazar was mentioned explicitly in Chapter 6, the names of the mother and seven brothers remain unknown. ${ }^{10}$ It is also intriguing that their father is not mentioned at all. ${ }^{11}$

One of the central motifs that the writer emphasizes is the insistence of faithfulness to the Law, even in the most challenging circumstances of painful torture, all for the sake of cleansing away sin and the salvation of all the Chosen People (7:32-28). However, the two most interesting topics that the $2 \mathrm{Macc}$ addresses are the firm belief in resurrection after death and the idea that God created the world out of nothing. Schwartz, who sees Chapters 6 and 7 as two halves of one whole narrative, skillfully put together by the epitomator, states

8 See: Session, 2019.

9 Lash, 2007, 217-234.

1o Their names are not written even in 4 Macc. However, its Latin translation brings the mother's name: Solomonia, while Syriac writer Aphrahat ( ${ }^{\text {th }}$ Century) gives her name: Samuna (Shmuni). Gwynn, 1989, 360. For the Syriac and Armenian tradition see also: Witakowski, 1994, 153-168. The medieval chronicle of Jewish history Josippon (ca. 10 $0^{\text {th }}$ Century) calls her Hannah. Nevertheless, the Greek Synaxarion of the Church of Constantinople ( $10^{\text {th }}$ Century) lists names of mother: Solomone ( $\Sigma \mathrm{o} \lambda \mathrm{o} \mu \mathrm{ov} \tilde{\eta})$ and brothers: Abim, Antonius, Gurias, Eleazar, Eusebonus, Samonas and Marcellus. Delehaye, 1902, 861.

11 R. Doran has an idea that author did this intentionally. He wanted to show who the real father of the children is. According to him, God is the true father of the children, who show their lineage by obeying his laws. Doran, 2012, 166. 
that the narrative of the martyrdom of mother and brothers complements the previous narrative related to Eleazar, and allows Jews of all ages and sexes to see themselves in the concept of martyrdom. ${ }^{12}$ Apart from the belief in resurrection and the creation of the world from nothing, the motifs of suffering because of $\sin (7: 18.32-33.38)$, suffering for the law (7:2.9.11.23.30.36.37) and punishment that will catch up to the tormentors, that is, the king himself ( $7: 14 \cdot 17.19 \cdot 31.34-36)$ are all to be found in this chapter.

\subsection{Structure and Content of the 2 Macc 7}

The seventh chapter begins with a brief preface (7:1) which introduces the brothers and their mother, who are arrested and forced by the king to eat forbidden swine meat. This is followed by a speech from the first brother in which he insists on staying true to the ancestral laws, namely the Torah $(7: 2)$. The king's anger at this declaration is then described, followed by the brutal death of the first brother $(7: 3-5)$. In the next verse $(7: 6)$ the words of brothers and their mother are described, who quote Deut 32:36 (LXX), promising that God will reconcile Himself with His servants. ${ }^{13}$ After this, the writer details the torture of the second brother and his final speech, during which resurrection is mentioned for the first time ( $7: 8-9)$. Then the third, fourth, fifth, and sixth brother are described, and their words are quoted $(7: 11 ; 7: 14 ; 7: 16-17 ; 7: 18-19)$. In the speeches of the third and fourth brothers (7:11 and 7:14), resurrection is also mentioned.

After describing the suffering of the sixth brother, the writer reintroduces the mother to the scene. He describes her ( $7: 20)$, quoting the words that she spoke to each son in "the ancestral language." ${ }^{4}$ In her speech, one can also find allusions to resurrection (7:23). After failing to coerce the brothers into eating the forbidden meat, Antiochus tried to bribe the youngest brother, calling on his mother to persuade her youngest son to give up (7:24-26). The mother allegedly accepts the king's offer, but in the ancestral language, mocking the tyrant, she encourages her son to continue to follow the Law. She alludes again here to resurrection (7:29), as well as the idea of creating a world out of nothing $(7: 28)$. After this, the youngest brother's monologue is set out (7:30-38), which is also the longest (almost as long as the speeches of all the other brothers combined). This is followed by the death of the youngest brother $(7: 39-40)$ and the mother $(7: 41)$. The author ends narrative with his own words: "Let so much be said..." (7:42).

\section{The King of the Universe will raise us up to an eternal reviving of life}

Together with Dan 12 (which is to be dated only a few decades before the $2 \mathrm{Macc}$ ), Chapter 7 of $2 \mathrm{Macc}$ represents one of the oldest surviving texts

\footnotetext{
12 Schwartz, 2008, 298-299.

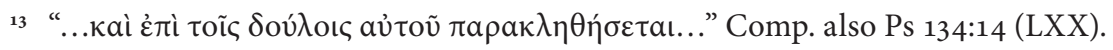

${ }^{14}$ Most likely it is a Hebrew language. See: Schwartz, 2008, 303; Goldstein, 1976, 297.
} 
thematizing faith in the resurrection of the dead. ${ }^{15}$ Faith in the resurrection is explicitly professed by both the second and fourth brother $(7: 9 ; 7: 14)$, and also by the mother in her first speech ( $7: 23)$. Allusions to the same topic can be found in the speeches of third and seventh brother $(7: 11 ; 7: 36)$, and in the second speech of the mother (7:29).

\subsection{Speech of the Second Brother}

Following the death of the first brother, the second brother is brought before the tormentors. After the brutal scenes of torture and his resolute refusal to eat the unallowed meat ( $7: 7-8)$, just before he dies, he says:

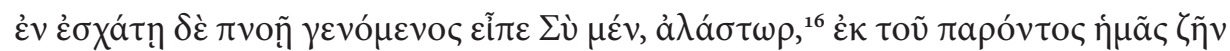

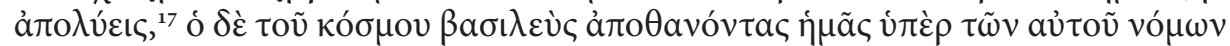

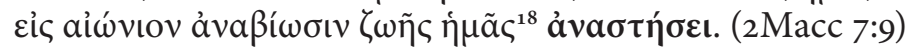

And when he was at last breath, he said: You wretch, you release us ${ }^{19}$ from our present living, but the King of the Universe will raise us up, us who died for the sake of His Laws, to an eternal reviving of life.

The speech of the second brother is the antithesis. With $\mu \varepsilon \dot{\varepsilon} v \ldots \delta \dot{\varepsilon}$, the author contrasts the king, or the wretch as he is also named (à $\lambda \dot{\alpha} \sigma \tau \omega \rho)$, and his control over the present life of the brothers with God, the king of the Universe, who controls the lives of all, present and future. ${ }^{20}$ As they suffer righteously for the

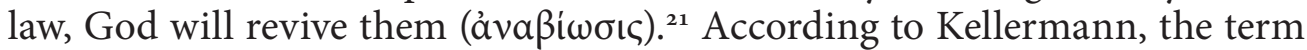

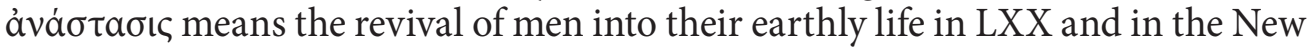
Testament (Is 26:19; Mark 9:27; Luke 16:31; John 11:23; Heb 11:35), and above all, resurrection at the end of time. ${ }^{22}$ Further, he states that here can one see an allusion being made to Dan 2:2: "And many of those... will arise, some to everlasting life..." ${ }^{23}$ However, unlike Daniel, where it can be concluded that there is

15 Comp. Berlejung, 2016, 582; See also: Schmitz, 2009, 105. But see also the development of the resurrection ideas in the LXX: Van der Kooij, 2007, 87-102.

16 In some manuscripts: $\alpha \lambda \alpha \sigma \tau o \rho$. See: Hanhart, 2017, 75. It is just uncontracted form.

17 In some minuscules: $\alpha \pi \mathrm{\pi} \lambda \lambda v \varepsilon ı$ c. See: Ibid. Probably just defect writing, which does not affect the meaning.

18 Origen omits $\dot{\eta} \mu \tilde{a} \varsigma$, See: Ibid.

19 The same verb was used in the previous chapter, when it was suggested to Eleazar that he could be freed from death by pretending to eat a forbidden meat. In Chapter 7, second brother wants to be freed from his present life, which is nothing in comparison with eternal life. Comp. Schwartz, 2008, 304

20 See: Doran, 2012, 157.

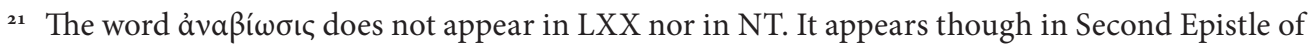
Clement (2 Clem 19:4) to describe the heavenly existence after death. It is to be found also by Josephus (Ant 18:14) with the similar meaning. See: Schmitz, 2009, 107.

${ }^{22}$ Kellermann, 1979, 64.

${ }^{23}$ Ibid., 63 . 
word of the resurrection at the end of time, here, the mention of any temporal determinant of resurrection is missing. The resurrection is simply transcendent. ${ }^{24}$

\subsection{Speech of the Fourth Brother}

After the death of the third brother, the fourth is brought before the torturers. Defying them, before he dies, he says:

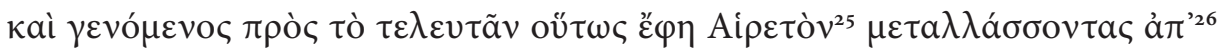

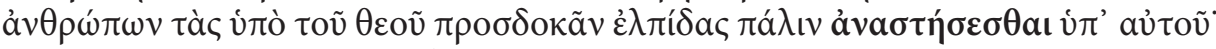

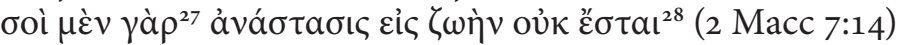

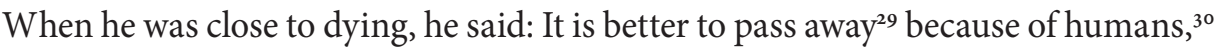
while from God expecting the hope again to being raised by Him. But for you there will be no resurrection into life.

As with the speech of the second brother, there is also antithesis here. Those who were martyred can hope for resurrection, while the king, because of his actions, will not have that opportunity. Here, too, according to Kellermann, an allusion is made to Dan 2:2. ${ }^{31}$ However, it is unclear whether Antiochus is going to have the resurrection to everlasting shame and contempt, or simply he will face eternal death. ${ }^{32}$ As Schmitz notes, it is very interesting that the resurrection here is not presented as something certain, even if it is a martyr who is

${ }_{24}$ B. Schmitz calls it "himmlisch-transzendent." Schmitz, 2009, 107.

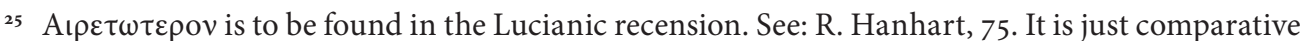
form, witnessed also in latin translations: LB and LM. See: De Bruyne, 1932, 155. It is possible that the Lucian wanted to amplify the meaning of dying for the God, so the original form may be the positive form: aipetòv.

${ }^{26}$ In some manuscripts: $\dot{u} \pi$ '. See: Hanhart, 2017, 75. In terms of meaning, both variants are fine. The second variant suits more to later Latin translations that use the preposition $a b$. See: De Bruyne, 1932, 154-155. The Church Slavonic translation used the proposal $\bar{w}$, which could encompass both Greek variants. See: Славянская Библия, Donetsk, 2002, 3402.

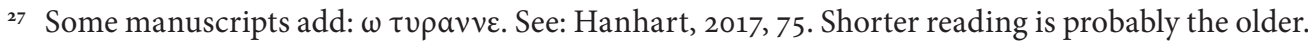
The addition was probably intended to emphasize Antiochus' cruelty, which is already sufficiently emphasized in the text.

${ }^{28}$ In some minuscules: $\varepsilon \sigma \tau \imath(v)$. See: Ibid. It is just the present form of $\varepsilon i \mu$ i. Since the Latin translations all offer the future form, it is almost certain, that the older reading is the future form:

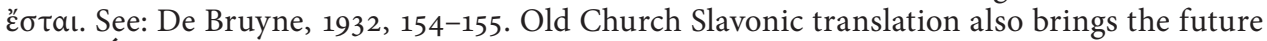
form: Б8́_AЕT々. Seе: Славянская Библия, Donetsk, 2002, 3402.

29 The verb $\mu \varepsilon \tau \alpha \lambda \lambda$ á $\sigma \sigma \omega$ literally means "to change, alter or to exchange" and is frequently used figuratively in 2 Macc for "to die" (4:7; 5:5; 6:31; 7:7.13.40; 14:46). Doran, 2012, 158.

${ }^{30}$ R. Doran and D. Schwartz translate this as "pass away among men," meaning to leave from human existence. See: Doran, 2012, 158; Schwartz, 2008, 306. On the other hand A. Jevtić, B. Schmitz and NETS translate this as "at the hands of human beings." See: Jevtić, 2002, 175; Schmitz, 2009, 108. J. Bartlett translates also similarly to Jevtić, Schmitz and NETS: "Better to be killed by men." Bartlett, 1973, 271.

${ }^{31}$ See: Kellermann, 1979, 67.

${ }^{32}$ U. Kellermann thinks that the latter is the case. Ibid. See also: Nickelsburg, 1972, 95. 
justly suffering, but rather is it presented as hope. Hope in God, who is the one who resurrects. ${ }^{33}$

\subsection{Speech of the Mother}

The mother also speaks directly about the resurrection in her first speech. After she explains that she was not the one who gave life to her sons (7:23), she continues:

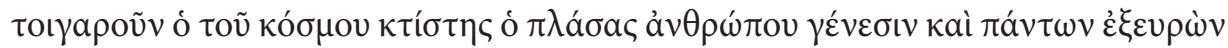

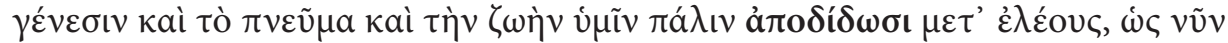

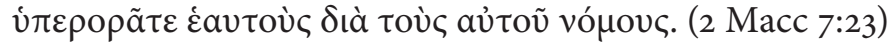

Therefore the Creator of the Universe, the Designer of origin of men and of all things Inventor, he also gives back again your life and spirit with mercy, as you now disregard yourself for the sake of His Laws.

The idea of resurrection in the mother's speech is closely linked to the idea of creation, which shall be addressed below. Since God created the world, He is also able to restore the spirit and life of her sons. What is important here is that God resurrects with His grace.

The speech of the third brother, who is hoping to receive (ко $\mu i \zeta \omega)$ his tongue and his hands back from God (7:11) also testifies the faith in the resurrection. The same occurs during second speech of the mother, who is urging her youngest

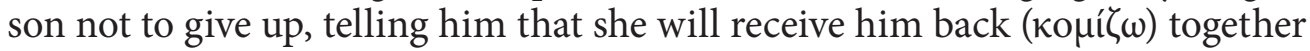
with his brothers (7:29). Also, the youngest brother speaks (7:36) of his brothers who have fallen, enduring pain and suffering for everlasting life ( $\dot{\eta} \alpha \dot{\varepsilon} v a \eta \zeta \omega \eta \dot{\eta})$. There is one curious element to the speech of the third brother: he represents life after death as similar to this life - namely, he will regain his limbs, thus referring to the resurrection as the resurrection of the body also. ${ }^{34}$ In any case, faith in the resurrection as explored in the speeches of the mother and brothers is undoubtedly biblical. It is that faith which one can find in Is 26 , but it is also the same kind of faith professed in Dan $12,{ }^{35}$ as well as in the motifs of the community of the righteous with God, brought by Ps 49 and Ps 73:23-26. ${ }^{36}$

What is important to note is that biblical faith in the resurrection as detailed in 2 Macc 7 differs significantly from similar ideas seen in Hellenistic environment of the time that the author was living in. As Kellermann states, there are three motifs to be found in the literary forms of the Hellenistic world, similar

\footnotetext{
33 Schmitz, 2009, 107.

34 Ibid.

35 Dan 12 is even more interesting, since it was written only a few decades before the $2 \mathrm{Mac}$. See: Von Dobbeler, 1997, 202.

36 Kellermann, 1979, 84.
} 
to what the writer of $2 \mathrm{Macc} 7$ narrates. The first is the hope of Greek folk piety into heavenly immortality, the second, closely related, is the Greco-Roman notion of celebrating the heroic death of soldiers, and third, the Egyptian faith in the resurrection. ${ }^{37}$

Greek folk piety, a motif most commonly recorded on tombstones, expresses the expectation of the ascension of the soul after death to the heavenly world. One such epitaph is about the death of a certain Menelaos:

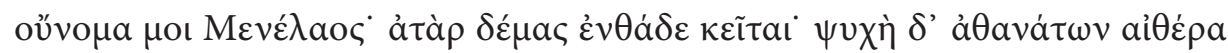
vaııนáci $i^{38}$

My name is Menelaos. Only body here lies, but soul dwells in Ether immortal.

However, if one looks closely at the speeches of the brothers, the dualism of body and soul appears to be unknown to the epitomator. 2 Macc 7 (but also the other sections of the Bible mentioned above) speaks of the definitive death of man, and the hope for resurrection by God. This Greek idea of immortality, according to Kellermann, stands in contrast to the faith in God who creates the world. ${ }^{39}$ Biblical faith in the resurrection is not some waste desire for the infinite extension of life, but faith in justification, in the transfiguration of the resurrected only through God.

The Greco-Roman notion of celebrating the heroic death of soldiers is similar to the idea explored above. Only special men who have fallen in battle can hope to escape the fate of Hades, and their soul will go to another place, similar to that of Menelaos. ${ }^{40}$ However, the author of 2 Macc 7 professes faith that both the brothers and the mother will be resurrected.

Finally, the Egyptian writings are testament to the centuries-old faith in eternal life, resurrection and the ascension of the dead to the kingdom of Osiris. ${ }^{41}$ At first, resurrection was reserved only for rulers, but during the Hellenistic period, it was democratized so that all the dead could hope for eternal life..$^{2}$

So, you go forth to where your mother Nut is, and she takes hold of your arm and gives you the way to the Akhet, to the place where the Sun (Ra) is. The sky's door is opened to you, the Cool Waters' door is made to pull open to you, and you find the Sun (Ra) standing, waiting for you. He takes hold of your arm, leads you into the sky's dual shrines, and puts you on Osiris's throne. ${ }^{43}$

37 Ibid., 89.

${ }^{38}$ Betz, 2011, 111.

39 Comp. Kellermann, 1979, 90.

40 Ibid.

${ }^{41}$ Ibid., 91.

42 Ibid., 92.

43 Utterance 422. See: Allen, 2015, 105. 
Yet, as Kellermann notes, despite similar terminology, biblical faith as it is expressed in $2 \mathrm{Macc} 7$ differs across many aspects. ${ }^{44}$ Concerning the Egyptian beliefs, resurrection is conditioned by an adequately performed funeral. It is not God who resurrects, but a properly performed magic ritual, because immortality is in man himself. As Kellermann writes, the heavenly resurrection is actually reflected through the existence of some kind of mummy "doppelgänger."45 However, in $2 \mathrm{Macc} 7$, the One able to resurrect is God, who resurrects by his grace (7:23.29). Those who are resurrected are not doppelgängers, but complete humans with body and soul, as the Creator created them (7:11.23).

That being said, biblical faith in the resurrection is, in many ways, different from similar concepts found in the Hellenistic world. The biblical faith in resurrection is indeed something unique, which, at least in the Christian view, will only be fully revealed and explained in the event of Christ.

Why was faith in the resurrection revealed? S. von Dobbeler, similarly to Kellermann, concludes that the idea certainly did not come from a mere desire to extend earthly life, but rather from the need to understand the recent persecutions and the violent deaths of those who firmly believed in God and obeyed His Laws. Where had God, who revealed himself at Sinai and promised to be with his people, disappeared to? Did he just hand them over to the tormentors? No: God remains faithful to his people, even after death, von Dobbeler concludes, because $\mathrm{He}$ is the one who has power over death and who will bring the dead back to life. ${ }^{46}$ Those who rejected Him through the act of destroying His creation, they will get what they deserve, just as the brothers state in their monologues. God, who is able to create the whole world, will resurrect those who obey His Law.

\section{He who made them from what not exist}

In addition to faith in the resurrection, in Chapter 7 one can also find the teaching that God is the Creator, who created the world out of nothing. In her second speech, encouraging her youngest son not to give up, the mother says the following:

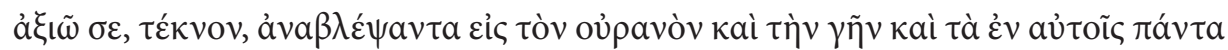

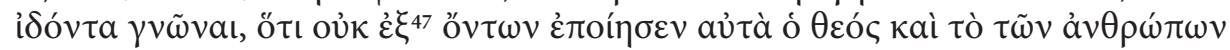

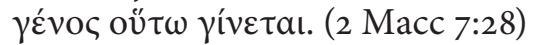

44 Kellermann, 1979, 92.

45 Ibid., 93.

46 Von Dobbeler, 1997, 202.

47 According to R. Hanhart $\grave{\varepsilon} \xi$ oủk öv $\tau \omega v$ can be found in the Lucianic recension. See: Hanhart,

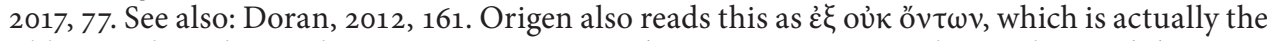
oldest reading that we have. See: GCS 10, In Iohanem, 22. Cyprian also reads ex nihilo. CCSL 3, Ad Fortunatum, 209. Origen and Cyprian are both older than Lucianic recension and Codex Alexandrinus. But since the Alexandrinus is the oldest complete manuscript of 2 Macc, for now the Hanhart's reading has advantage. 
I beg you, child, looking upon the heaven and earth, and seeing all things that are in them, to know that from what not exist ${ }^{48}$ made them God and thus the humankind becomes.

In the textual traditions, one could already note the potential tensions in the order of words when it addresses how God created the world. The oldest complete manuscripts (A) record ov̉ $\dot{\varepsilon} \xi$ ő $v \tau \omega v$, while those, according to R. Hanhart, derived from the Lucianic recension, record $\dot{\varepsilon} \xi$ oủк oै $v \tau \omega v$. Are these synonyms, or is Lucian's correction actually made to avoid the possible ambiguity of this statement? Some scholars, like May, argue that in both textual variants, there is no trace of creatio ex nihilo, but that the writer of $2 \mathrm{Macc}$, as a Jew from the Diaspora, was representing a position similar to that of Greek philosophers, according to whom the world was formed through the shaping of pre-existing matter. ${ }^{49}$ Accordingly, both readings could be interpreted as: "even though certain things did not exist, God creates the world from already existing formless matter," or "after they (the created objects) had not existed (as such, but only as preexistent matter), God creates them." ${ }^{\text {"5o }}$ So, this would mean that God is the creator, who takes heaven and earth from their non-existence, because they did not exist in that form before, as heaven and earth, but as some formless matter, and he brings them into existence.

According to May, the idea of creatio ex nihilo emerges from Christian theologians only in the second half of the second century, as a product of a philosophical attempt to combat Gnostic heresies such as Valentinianism which, under the strong influence of Greek philosophy, taught that it was not God, but another creature, the Demiurge, that created or shaped the world. Christian theologians, such as Irenaeus of Lyon and Hippolytus of Rome, being well acquainted with philosophical principles, considered the source of this teaching to be a Platonic notion of creation from pre-existing matter. Since this view of God was unacceptable for them, and as was the introduction of some other creator, these Christian theologians postulated that the biblical God is actually the Creator, who creates the world ex nihilo. ${ }^{51}$ Otherwise, the world would be co-eternal with God, and therefore it could not be said of God that He is the Creator of Heaven and Earth and the Pantocrator.

Indeed, this view is reliant upon Greek philosophers, for whom the idea of creation out of nothing was unimaginable. They emphasized that "nothing cannot arise from what does not exist." ${ }_{52}$ This is also confirmed by Aristotle when he says that this is the "dogma of the philosophers," and that almost everyone

\footnotetext{
${ }^{48}$ Literally: Not from what exists made them (heaven and earth) God.

49 For example: May, 1978, 6-8. Also, Goldstein states that the Platonists called pre-existent matter the non-existent ( $\left(\grave{o} \mu\right.$ ì̀ öv). Goldsten, $1984^{\mathrm{b}}, 127$.

5o Goldstein, 1984 , 308; Goldstein, 1984 ${ }^{\mathrm{b}}, 127$.

51 May, 1978, 25-26.

52 Goldstein, $1984^{\mathrm{b}}, 127$.
} 
agrees with it. ${ }^{53}$ In addition, Goldstein assumes that at the time of the emergence of $2 \mathrm{Macc}$, there was no philosophical school that could accept (or postulate) the idea of creatio ex nihilo. ${ }^{54}$

However, what does the $2 \mathrm{Macc} 7$ really tell us? Before attempting to answer that question, it must be kept in mind that this book is, first and foremost, a historical account of the events that took place in Palestine on the eve of the Maccabean uprising and its outbreak..$^{55}$ In addition, this is a biblical book which does not seek to provide a detailed systematic exposition of faith, ${ }^{56}$ as later do, e.g. the Christian Creeds. 2 Macc 7 underlines that faith in God should be considered as central. In God who is, above all, present and revealed in history, the Creator, the Almighty, the Mighty Ruler of Heaven. The author aims to emphasize the importance of following His Laws. God is the omnipotent Pantocrator, and from there, faith in the resurrection, and with it related faith in the creation of the world out of nothing, is indirectly derived. ${ }^{57}$

Indeed, Goldstein is correct in saying that the idea of resurrection, especially the bodily resurrection that one reads about in $2 \mathrm{Macc} 7$, but also in Is 26:19 and Dan 12:2, also requires a direct understanding of God as one who can create everything from something that does not exist. ${ }^{58}$ If God is not capable of creating the world out of nothing, but can only shape it from some eternal existing matter, then the resurrection of the body is impossible, especially the kind that the third brother believes in (7:11). For example, if the first brother was burned alive and the smoke rose from the torture room to the heavens (7:5), how will he be ex nihilo resurrected by God, who is only the designer? Only the Creator who creates the world from nothing, from a non-being that does not have its own existence, can also resurrect those who have returned to non-being through death. Thus, as Goldstein says, even resurrection of the body (and with it the spirit - 7:22) is ex nihilo. 59

So, if one accepts the theory that the author held such firm faith in the resurrection of the body, and therefore in the Creator, who creates the world out of nothing, then it is unclear how Goldstein was able to come to the conclusion that he did not incorporate this idea into his work. ${ }^{60}$ Rather, Goldstein posits,

53 Met 11.6, 330.

${ }_{54}$ Goldstein, $1984^{\mathrm{a}}$, 309.

55 D. Schwartz writes: "However, our book is not a philosophical tract, and the lack of precision is not sufficient reason to reject the exegetical tradition which, beginning with Origen, indeed sees here the doctrine of creation ex nihilo." Schwartz, 2008, 312.

${ }^{56}$ After all, neither do the New Testament writings.

57 Schmitz, 2010, 107.

${ }^{8}$ Goldstein, $1984^{\mathrm{b}}, 131$.

59 Ibid., 129.

6o "Though he did not go so far as to assert creation ex nihilo, he bases the belief in resurrection upon the power of God as creator." Ibid., 130. 
the author only argues with skeptics, such as Sadducees, who did not believe in the resurrection or with the Ecclesiastes (3:1.9-21; 9:2-6). According to Goldstein, the epitomator exclusively defends the idea of the resurrection, and the idea of creation found in this work was most likely derived in a later period when the Fathers of the Church developed such teachings. ${ }^{61}$ As stated, the writer certainly did not intend to systematically expose cosmological principles, but it is indeed challenging to assume that he did not imply such an understanding in his writings. A similar conclusion is reached by Copan, who quotes Gerhard von Rad: "The conceptual formulation creatio ex nihilo is the first found in this (7:28) passage." ${ }^{\prime 2}$ For Copan, this teaching is biblical, and, in opposition to May, he states that it is completely pointless to say that it is not biblical, just because it is at the later time, in a collision with heretical teachings, formulated in more detail. By the same logic, the whole of Christian Triadology and Christology could be denied, because they were formulated in more detail first in a collision with certain heretical teachings. ${ }^{63}$

\section{Conclusion}

The ideas espoused in Chapter 7 of the 2 Macc have made its creation one of the most exciting moments in all Deuterocanonical literature. It could be said that because of its subject matter, it represents one of the most important chapters of the Old Testament. Since the time of Origen (though it was not excluded even at the time of the Shepherd of Hermas), this narrative has been used to biblically support the idea that God has created the world from nothing. ${ }^{64}$ Chapter 7 , for the first time, explicitly develops the idea of the resurrection from the dead, which involves both the resurrection of the soul and the resurrection of the body. It could be said that these teachings are very similar, if not the same, to those encountered in the New Testament. It is interesting, however, that at least for the first four centuries, Christian writers did not use the words of the mother or brothers at all to explain the teaching of the resurrection. The only allusions to this can be found in the Catecheses of Cyril of Jerusalem, ${ }^{65}$ while Origen, for example, makes no mention of the resurrection when he quotes the $2 \mathrm{Macc}^{66}$

Besides these two very important ideas, the cult of marytrdom is certainly an area where $2 \mathrm{Macc} 7$ has been most influential. The seven brothers and their mother were perceived as arch-martyrs, examples for all those who suffer in times of persecution. Gregory the Theologian and John Chrysostom dedicated central

\footnotetext{
${ }^{61}$ Goldstein, 1984a, 311.

${ }_{62}$ Von Rad, 1996, 85.

${ }_{63}$ Copan, 1996, 92-93.

${ }^{64}$ SC 53, Hermas, 78; Behr, 2017, 152-153; GCS 10, Origen - In Iohanem, 22; PG 17, Origen - In Proverbia, 196.204; PG 14, Origen - Ad Romanos, 979, etc.

${ }_{65}$ Reischl и Rupp, 1967ª 122; Reischl и Rupp, 1967 312.

${ }^{66}$ See for example: Behr, 2017.
} 
parts of their Maccabeean homilies to them. ${ }^{67}$ As such, they were celebrated by the Christians as saints no later than the mid-fourth century. Once persecution of the Early Church had ceased, their struggle was understood on a spiritual level, as a fight against the invisible Antiochus, embodied in passions and sins. 
52 | Danilović, A., Faith in Ressurrection of the Dead and Creatio ex nihilo in 2 Macc 7

\section{Bibliography}

Abel, F.-M. (1949). Les Livres des Maccabées (Éstudes bibliques 40). Paris: Les Éditions du Cerf.

Allen, J.P. (ed). (2015). The Ancient Egyptian Pyramid Texts. Atlanta, Georgia: SBL Press.

Bartlett, J.R. (1973). The First and Second Books of the Maccabees. Cambridge: University Press.

Behr J. (ed). (2017). Origen - On First Principles: Volume I (Oxford Early Christian Texts). Oxford: Oxford University Press.

Berlejung, A. (2016). Die Makkabäerbücher. In J.C. Gertz (ed), Grundinformation Altes Testament.Eine Einführung in Literatur, Religion und Geschichte des Alten Testaments (pp 576-579). Göttingen: Vandenhoeck \& Ruprecht.

Betz, H.D. (2011). "A child of Earth am I and of starry Heaven" Concerning the anthropology of the Orphic gold tablets. In R.G. Edmonds III (ed), The "Orphic" Gold Tablets and Greek Religion: Further along the path (pp 102119). Cambridge: Cambridge University Press.

Copan, P. (1996). Is Creatio Ex Nihilo a Post-Biblical Invention? An Examination of Gerhard May's Proposal. Trinity Journal 17, 77-93.

De Bruyne, D. (ed). (1932). Les anciennes traductions latines des Machabées (Anecdota Maredsolana 4). Maredsous: Abbaye de Maredsous.

Delehaye, H. (ed). (1902). Novembris propylaeum: Synaxarium Ecclesiae Constantinopolitana - e codice sirmondiano. Brussels: Socios Bollandianos.

Doran, R. (2012). 2 Maccabees: A Critical Commentary (Hermenia - A Critical and Historical Commentary on the Bible). Minneapolis: Augsburg Fortress.

Goldstein, J.A. (1976). I Maccabees: A New Translation with Introduction and Commentary, (The Anchor Bible 41). New York: Yale University Press.

Goldstein, J.A. $\left(1984^{\mathrm{a}}\right)$. II Maccabees: A New Translation with Introduction and Commentary, (The Anchor Bible 42). New York: Yale University Press.

Goldstein, J. (1984 $\left.{ }^{\mathrm{b}}\right)$. The Origins of the Doctrine of Creation Ex Nihilo. In G. Vermes (ed), Journal of Jewish Studies 35. Oxford.

Gwynn, J. (1989). Selections Translated into English from the Hymns and Homilies of Ephraim the Syrian and from the Demonstrations of Aphrahat the Persian Sage (Nicene and Post-Nicene Fathers of the Christian Church 2.13). Edinburgh: T \& T Clark.

Habicht, C. (1976). 2 Makkabäerbuch (Jüdische Schriften aus hellenistich-römischer Zeit I.3). Gütersloh: Gütersloher Verlagshaus Gerd Mohn.

Hanhart, R. (ed). (2017). Maccabaeorum liber II. Septuaginta. Vetus Testamentum Graecum (Auctoritate Academiae Scientiarum Gottingenensis editum 9/2). Göttingen: Vandenhoeck \& Ruprecht. 
Jevtić, A. (2002). Knjige Makavejske. Trebinje/Nikšić/Vrnjci: Jasen.

Kellermann, U. (1979). Auferstanden in den Himmel: 2 Makkabäer 7 und die Auferstehung der Märtyrer (Stuttgarter Bibelstudien 95). Stuttgart: Verlag Katholisches Bibelwerk.

Lash, E. (2007). The Canon of Scripture in the Orthodox Church. In P.S. Alexander, J.D. Kaestli (ed), The Canon of Scripture in Jewish and Christian Tradition (pp 217-234). Prahins: Éditions du Zèbre.

May, G. (1978). Schöpfung aus dem Nichts: Die Entstehung der Lehre von der Creatio ex nihilo (Arbeiten zur Kirchengeschichte 48). Berlin-New York: W. de Gruyter.

Nicklesburg, G.W.E. (1972). Resurrection, Immortality and Eternal Life in Intertestamental Judaism (Harvard Theological Studies XXVI). Cambridge: Harvard University Press.

Reischl, W.C., Rupp J. (ed). (1967ª). Cyrili Hierosolymarum archiepiscopi opera quae supersunt omnia Vol. I. Hildesheim: Olms.

Reischl, W.C., J. Rupp (ed). (1967 ). Cyrili Hierosolymarum archiepiscopi opera quae supersunt omnia Vol. II. Hildesheim: Olms.

Schmitz, B. (2009). Auferstehung und Epiphanie. Jenseits- und Körperkonzepte im Zweiten Makkabäerbuch. In T. Nicklas, F. V. Reiterer, J. Verheyden (ed), The Human Body in Death and Resurrection (pp 105-142). Berlin/ New York: W. de Gruyter.

Schmitz, B. (2010). Geschaffen aus dem Nichts? In T. Nicklas, K. Zamfir (ed), Theologies of Creation in Early Judaism and Ancient Christianity (pp 61-80). Berlin/New York: W. de Gruyter.

Schwartz, D.R. (2008). 2 Maccabees (Commentaries on Early Jewish Literature). Berlin/New York: W. de Gruyter.

"Session 11 on 4. February 1442 in Council of Basel-Ferrara-Florence, 1431-49 A.D.” IntRes: https://www.papalencyclicals.net/Councils/ecum17.htm Retrieved: 09.07.2019.

Van der Kooij, A. (2007). Ideas About Afterlife in the Septuagint. In M. Labahn и М. Lang (ed), Lebendige Hoffnung - ewiger Tod?! Jenseitsvorstellungen im Hellenismus, Judentum und Christentum (ABG 24) (pp 87-102). Leipzig: Evang. Verl.-Anst.

Von Dobbeler, S. (1997). Die Bücher 1 und 2 Makkabäer (Neuer Stuttgarter Kommentar.Altes Testament 11). Stuttgart: Katholisches Bibelwerk.

Von Rad, G. (1962). Old Testament Theology, Vol. 1. New York: Oliver and Boyd. Witakowski, W. (1994). Mart(y) Shmuni, the Mother of the Maccabean Martyrs in Syriac Tradition. In R. Lavenant (ed), VI Symposium Syriacum (Orientalia Christiana Analecta 247) (pp 153-168). Rome: Pontificio Istituto orientale. 


\section{Александар Даниловић}

Хришћански културни центар др Радован Биговић, Београд

\section{Bepa у васкрсење из мртвих и стварање ex nihilo у 2 Мак 7}

И звештај о страдању седморице браће и њихове мајке је оставила много трага у историји рецепције како Цркве, тако и Синагоге. Култ Макавејских мученика почео се развијати веома рано, да би најкасније у четвртом веку међу хришћанима они били прослављани као светитељи. Прича о њима се налази у седмом поглављу Друге Књиге Макавејске, чији је статус у последњих неколико векова, како међу православнима, тако и шире, постао предмет расправа. Синагога је ову књигу у целости одбацила, иако се у њој крије најстарије забележено сведочанство о прослављању Хануке, једног од најважнијих јудејских празника данас. Међутим, прича о мајци и браћи је у одређеној форми остала сачувана у Талмуду. Поред приче о мученичком страдању, у седмом поглављу се крије једно од најстаријих, и свакако најсликовитијх описа ране вере у васкрсење из мртвих. Осим тога, седмо поглавље открива најстарију експлицитно изражену веру у Бога, који је апсолутни Творац и који ствара свет из ничеїа. Ова идеја ће касније постати један од централних мотива хришћанске, али и јудејске космологије.

Key words: васкрсење, стварање, ex nihilo, Макавеји, мученици, Стари Савез, девтероканонске књиге.

Датум пријема чланка: 15. 10. 2020.

Датум прихватања чланка за објављивање: 19. 10. 2020. 